\title{
Health Rights of Refugees, Immigrants and Asylum seeker*
}

\author{
Parisa Yaghoub-Pour ${ }^{1}$, Hosein Dadashzadeh Asl² \\ Ankara University, Ankara, Turkey
}

10.15408/jch.v9i2.20739

\begin{abstract}
It has been widely documented that refugees are one of the most vulnerable layers of society to health problems due to poor access to social services, as well as difficulties in housing and nutrition, poor living conditions, and abuse. The health services provided to IDPs are often inadequate and appropriate. Refugees and immigrants have difficulty accessing health care services, medicines, counselling, diagnosis, treatment and rehabilitation services almost all over the world. Today, inequality, regional struggles, and global shifts strongly reflect the ongoing problems of refugees and migrants and their future escalation. This study uses a qualitative research method with a literature approach. The results of the study stated that the settlement of matters regarding their stay, nutrition, accommodation and health services must be prepared in advance, and especially human rights must be respected. In this regard, the actions of governments, civil society organizations and universities at the regional and global levels will contribute to a better future of immigration.

Keywords: Refugees and Immigrants; International Immigration; Health Law; Health problems; Health services; Convention Regarding the Status of Refugees
\end{abstract}

* Received: February 12, 2021, revised: April 16, 2021, accepted: June 18, 2021, Published: 31 August, 2021.

1 Department of Law, Ankara University, Ankara, Turkey Email: yaghoobpour@ankara.edu.tr https://orcid.org/0000-0001-7118-8678

${ }^{2}$ Department of Law, Ankara University, Ankara, Turkey Email: hs.dadashzadeh@gmail.com https://orcid.org/0000-0001-8100-3307 


\title{
Hak Kesehatan Pengungsi, Imigran dan Pencari Suaka
}

\begin{abstract}
Abstrak
Telah banyak didokumentasikan bahwa pengungsi adalah salah satu lapisan masyarakat yang paling rentan terhadap masalah kesehatan karena buruknya mendapat layanan sosial, selain karena kesulitan dalam perumahan dan gizi, kondisi hidup yang buruk, dan adanya pelecehan. Pelayanan kesehatan yang diberikan kepada pengungsi seringkali tidak cukup dan layak. Pengungsi dan imigran mengalami kesulitan mengakses layanan perawatan kesehatan, obat-obatan, konseling, diagnosis, pengobatan dan layanan rehabilitasi hampir terjadi di seluruh dunia. Saat ini, ketidaksetaraan, perjuangan regional, dan pergeseran global sangat mencerminkan masalah pengungsi dan migran yang terus berlanjut dan eskalasi mereka di masa depan. Penelitian ini menggunakan metode penelitian kualitatif dengan pendekatan literatur. Hasil penelitian menyatakan bahwa penyelesaian urusan tentang masa tinggal mereka, nutrisi, akomodasi dan layanan kesehatan harus disiapkan terlebih dahulu, dan terutama hak asasi manusia harus dihormati. Dalam hal ini, tindakan pemerintah, organisasi masyarakat sipil dan universitas di tingkat regional dan global akan berkontribusi pada masa depan imigrasi yang lebih baik.

Kata Kunci: Pengungsi dan Imigran; Imigrasi Internasional; Hukum Kesehatan; Masalah kesehatan; Pelayanan kesehatan; Konvensi Terkait Status Pengungsi
\end{abstract}

\section{Права на здоровье беженцев, иммигрантов и просителей убежища}

\begin{abstract}
Аннотация
Широко задокументировано, что беженцы являются одним из наиболее уязвимых слоев общества с точки зрения проблем со здоровьем из-за плохого доступа к социальным услугам, а также трудностей с жильем и питанием, плохих условий жизни и жестокого обращения. Медицинские услуги, предоставляемые беженцам, часто неадекватны и не соответствуют требованиям. Беженцы и иммигранты почти во всем мире испытывают трудности с доступом к услугам здравоохранения, лекарствам, консультациям, диагностике, лечению и реабилитации. Сегодня неравенство, региональная борьба и глобальные сдвиги во многом отражают текущие проблемы беженцев и мигрантов и их будущую эскалацию. В этом исследовании используется качественный метод исследования с литературным подходом. Результаты исследования показали, что решение вопросов, касающихся их пребывания, питания, проживания и медицинского обслуживания, должно быть подготовлено заранее, и особенно должны соблюдаться права человека. В этом отношении действия правительств, организаций гражданского общества и университетов на региональном и глобальном уровнях будут способствовать лучшему будущему иммиграции.
\end{abstract}

Ключевые Слова: Беженцы и иммигранты; международная иммиграция; закон о здоровье; проблемы со здоровьем; медицинские услуги; конвенция о статусе беженцев 


\section{A. INTRODUCTION}

Among the most significant challenges of the modern world are the issues related to immigration and seeking asylum. Especially at a time when globalization is taking place due to the rapid fluctuations in the world economy, people from societies in which the order of life is disturbed are forced to migrate to other countries in order to fashion themselves new - and better living conditions. In the current global climate, one of the direst challenges facing humanity is the issue of immigration and seeking asylum.

Seeking asylum, a trend directed from poorer countries to richer ones, has created a plethora of border-related problems. In countries where straightforward border crossings are amiss, millions of hungry people seek to go, either legally or illegally, to new countries via water. Accordingly, as evidenced by the sheer volume of daily news broadcast on television, thousands of poor people lose their lives as ships and boats sink. As long as these reprehensible deaths and suffocations occur owing to the irresponsibility and negligence in the side of governments, such difficulties will only continue to escalate, and as a result, millions of hungry and unemployed people will try to emigrate from poor countries to rich ones.

As the increasing demands of humanity has led governments to more trying measures, rich countries assume priority in meeting the needs of their people. Therefore, people who have accepted asylum and are in challenging circumstances need rich countries to welcome and entertain them in order to solve their problems and restore their living conditions to the desired level.

Health rights are one of the rights that refugees should enjoy like other members of society. In this paper, the author seeks to highlight the significance of the health rights of people who have been forced to emigrate and discuss the measures that should be adopted beforehand to create a healthier society. Governments and international organizations must collaborate to ensure that the health of countries that welcome asylum-seekers is not disturbed.

\section{B. METHODS}

This study uses a qualitative research method with a literature approach. The data used comes from realities in the field by conducting research and direct interviews. This study stated that the settlement of matters regarding their stay, nutrition, accommodation and health services must be prepared in advance, and especially human rights must be respected. 


\section{RESULTS AND DISCUSSION}

\section{The public view regarding immigrants and refugees}

Asylum, which is essentially a form of immigration, is a situation in which individuals do not feel safe in their home country because of their religious, political, and racial or ethnic views, and are therefore forced to leave their home country (Sur, 2012). Convention Relating to the Status of Refugees, also known as the 1951 Refugee Convention, a refugee is "a person who, owing to well-founded fear of being persecuted for reasons of race, religion, nationality, membership of a particular social group or political opinion, is outside the country of his nationality and is unable or, owing to such fear, is unwilling to avail himself of the protection of that country; or who, not having a nationality and being outside the country of his former habitual residence as a result of such events, is unable or, owing to such fear, is unwilling to return to it (UNHCR, 2018).

During the implementation of the 1951 Geneva Convention, agreements and regulations made at the regional level also expanded this concept.

As one of the regional legal instrument governing refugee protection in Africa regional legal instrument governing refugee protection in Africa, The Organization of African Unity (OAU) Convention Governing the Specific Aspects of Refugee Problems in Africa, also called the OAU Refugee Convention, or the 1969 Refugee Convention (UNHCR, 2018) focuses on refugee issues in Africa and creates special circumstances that have been able to expand the concept of asylum and migration. According to this convention, the definition of refugee is expanded to include "those forced to leave their permanent residence owing to external aggression, occupation, foreign domination or events seriously disturbing public order" (UNHCR, 1998, p. 314).

The treaty regarding the refuge of the member states of the Council of Europe refers to the conventions on refugees and the European Convention on Human Rights, which was concluded before this declaration, and as a commitment for the member states of the Council, the right to asylum was granted to those who seek asylum in these countries. In addition to the definition provided in the 1951 Geneva Convention, the Declaration also includes the granting asylum to asylum-seekers for "humanitarian reasons". With the addition of this, the Declaration made significant progress in terms of refugee rights.

Decisions of the League of Nations between 1922 and 1946 provide that a refugee must be outside the country of his or her nationality and hence cannot 
enjoy the protection of his/her original country in order to enjoy the rights granted to refugees (Chilkli, 2009). According to the 1951 Geneva Conventions and the ensuing 1967 Protocol, a refugee is "a person who, owing to wellfounded fear of being persecuted for reasons of race, religion, nationality, membership of a particular social group or political opinion, is outside the country of his nationality and is unable or, owing to such fear, is unwilling to avail himself of the protection of that country." The geographical scope of the united nations has also been expanded with this modification.

The notion of immigration is no longer a will-oriented notion and has become one with an obligatory nature. As such, migration is now more associated with forced relocation. Accordingly, a refugee can be defined as a person who has been forced to leave his or her country for various reasons (Cara \& Kercut, 2010).

Although attaining the status of refuge may vary depending on the destination country, there are some common conditions. These conditions are mainly regulated by the 1951 Geneva Convention and the ensuing 1967 Protocol. The basic conditions for gaining asylum can be grouped into four categories:

- As inferred from the definition, fear of persecution for valid reasons is a prerequisite (UNHCR, 1998, p. 15). The cause of fear must be the possibility of harassment. Asylum can also be granted at the request of individuals for reasons such as torture, aggression, unjust legal penalties, restrictions on political views and freedom of religion, serious violations of human rights and other specific reasons.

- Fear of harassment arising from a particular situation. This situation may be caused by race, ethnicity, religion, nationality, belonging to a particular group or political thought.

- At the time of applying for asylum, the person must be outside the country of nationality and the country where he or she is being harassed.

- The applicant either cannot or does not want to benefit from the support of the country to which he/she is a citizen to, or he/she cannot or is unwilling to return to the country.

Moreover, "an asylum seeker is a person who has a legitimate fear of torture in his or her own country or whose life is in jeopardy due to armed 
conflict and violence, and who therefore seeks asylum in another country (UNHCR, 1998, p. 20).

The term refugee is most commonly used for those who are awaiting finalization of their asylum application by the United Nations High Commissioner for Refugees (UNHCR) or the destination government. According to Article 33 of the Convention Relating to the Status of Refugees, refugees cannot be deported to their country of origin even if their status is not formally recognized (UNHCR, 1997, p. 183).

The term "asylum seeker" refers to persons whose application for asylum has not been finalized and to those who have not yet applied for residence. As a natural consequence of the principle of "Non-Refoulement to a place where there is oppression", these people should be treated in accordance with the human rights until their requests have been considered and resolved in fair manner and with due diligence, and hence should not be returned to their country (UNHCR, 2001, p. 22).

The terms refugee and asylum seeker are used interchangeably in Turkey. However, in practice it is observed that these terms are used to analyze situations. Asylum application in Turkey is yet assume its legal status and is in the process of establishment, and is a term used for people coming from outside Europe (Buze, 2002).

\section{Health rights of refugees and asylum-seekers}

Health rights are mostly provided through providing of health-care services to individuals. It can be said that health law consists of three pillars. The first is the right to preventive health-care services, which involves measures such as vaccination programs, clean water supply, and improved residential conditions. They can be applied to great effect to prevent external factors harming health and protect oneself thereagainst.

The second pillar of health law is the "right of access to medical resources." This right necessitates the provision of the essential infrastructure for medical requirements, the procurement of medicine for possible needs and the creation of accessible health facilities for the beneficiaries.

The constituent rights of the third pillar are rights such as the protection of medical data, the refusal of treatment and the choice of physician, which should generally be required from those who provide medical services (Özel Turk Tahmazoglu, 2012, p. 18). 
National and international law, in the frame of which health rights are defined, provides that health rights are one of the most fundamental human rights, regardless of whether the subjects are citizens of that country or not. Accordingly, immigrants, asylum seekers and refugees must also enjoy the right to health, and countries must ensure that this right is exercised in accordance with this law. In this regard, as well as the recognition of the rights that every person should have, refugees should also enjoy the rights and benefits that other non-citizens who are officially present in that country. As a result, refugees should be able to enjoy rights such as immunity from torture and ill-treatment, freedom of opinion, freedom of travel and proper access to health-care services (UNHCR, 2013).

It is often evidenced in large-scale immigration that some rights such as freedom of travel and freedom of work may be restricted by some states. The United Nations High Commissioner for Refugees (UNHCR) emphasized on providing basic needs if the host country's resources are insufficient and pursues policies to make asylum-seekers self-sufficient in short notice.

\section{Health problems of refugees and asylum seekers}

"Everyone has the right to food, clothing, housing and medical care for the health and safety of themselves as well as their families." As such, health rights are universal rights envisaged in the United Nations Convention on Human Rights as an integral part of the right to life. Health care for asylum seekers and refugees varies from state to state, but even in developed countries where more resources are available, health care levels are not enough. The opportunity to benefit from better medical or social services is only possible for the aforementioned people by obtaining a residence permit or citizenship. Asylum-seekers face serious difficulties in receiving preventive hygiene-based services and access to medication in diagnostic and treatment need all around the globe (Karadag \& Altinbash, K. Hakan. 2010, p. 56). Nevertheless, as recognized by a plethora of international laws, refugees and asylum-seekers, like other strata of societies, are entitled to the highest possible standards of physical and mental health (Buze, 2004, p. 144). However, inability to pay for medication and treatment, lack of access to health care, inability to fully manage one's illness due to difficulties pertaining to language, hesitation and inability to explain sexual abuse/harassment, inability to prove one's identity and ignorance of existing health services is one of the most common problems (Buze, 2004, p. 145). 
Asylum seekers and refugees in migration need health services more than any other strata sections of society due to problems such as accommodation, nutrition, protection, exposure to violence and access to social services, and due to problems in living conditions. In fact, problems with living conditions increase health problems (Karadag \& Altinbash, 2010).

As reported in international reports and articles, asylum-seekers and refugees often experience the following health problems (UNHCR, 2007): Nutritional deficiency/disorder; Growth disorders in children; Anemia; Diarrhea, measles, malaria, respiratory infections, infectious diseases; Physical violence and injuries caused by violence; Sexual harassment/assault; Sexually Transmitted Infections (STIs); Unwanted/high-risk pregnancies; Complications of childbirth and abortion; Chronic diseases and complications; Psychological problems, especially depression, anxiety disorders, sleep disorders and posttraumatic stress disorder (PTSD); Oral and dental complications

\section{Psychological problems of refugees}

$47 \%$ of the people included in the definition of a refugee in the world are asylum seekers who are forced to leave their country, 50\% of these refugees are women and 44\% are children under 18 years old (Guken, 2011, p. 119-126). According to the World Health Organization (WHO), health is "the perfect physical, mental and social condition." In addition to the economic and sociocultural problems in the country to which they migrate, asylum-seekers often suffer from severe hygiene-related difficulties. The situation in the country they were forced to leave and the way they currently live puts them under severe psychological pressure, hence causing them psychological issues (Ehntholt \& Yule, 2006). Factors that cause mental health complications can be evaluated in the pre-migration and post-migration conditions. As such, most asylum-seekers experience tragic events (loss of life, trauma and enduring events) resulting from the conditions that initially forced them to leave their country, while they suffer a plethora of mental and psychological problems due to the incompatibility, fragility, accommodation and communication problems in the destination country (Betancourt et al., 2011, p. 682-690). Many asylum-seekers and refugees either directly or indirectly experience events such as war, genocide, torture, rape and physical violence in the country they have left behind (Nicholl \& Thompson, 2004, p. 351-362). Furthermore, factors such as hazards during the travel, shattered family relationships, exposure to violence, difficult living conditions (refugee camps), and uncertainty in the destination country can also intensify the negative consequences during migration. Similar 
to their home country, refugees and asylum seekers continue to experience many difficulties, whether welcomed or not, after migrating. Difficulties such as difficulty finding jobs in the country of residence, socio-cultural differences, not knowing the language, concerns for family members who have remained in their country of origin, and loss of social status negatively affect their mental health. Studies have shown that the stress that asylum-seekers and refugees experience after migration is more detrimental to their mental health than the damage they experienced before migration (Teodorescu et al., 2012, p. 316-322).

Mental health disorders such as depression, sleep disorders, inferiority complex, suicide, agoraphobia, post-traumatic stress disorder and psychological symptoms are more common in asylum seekers and refugees (Buze, 2008, p. 1-14).

Post-traumatic stress disorder, insomnia, nightmares, recurring recurrences of events, anxiety about recurrence of events, hot-temperedness, inability to plan for the future, distress in situations reminiscent of events and avoiding them are among the symptoms most frequently reported. In most people suffering from traumas, the disease becomes traumatic within days of the event and usually resolves within a few weeks. However, post-traumatic stress disorder can last for months and, in some cases, years, as other conditions that cause stress to refugees persist (Ozturk \& Oglu Sahin, 2008, p. 496).

It is often observed that refugees and asylum-seekers experience depression and low morale when their expectations and hopes for the country to which they resort are not met and if they feel the possibility of losing their asylum rights. In depression, symptoms such as feelings of helplessness, dejected mood, inability to enjoy life, reluctance and weakness are frequently reported (Kirmayer et al., 2011, p. 959-966). Depression can occur for the first time immediately after experiencing trauma, or it can also recur for people who have history of previous depression. Post-traumatic stress disorder and anxiety disorder and depression are often assumed to be comorbid (Ehntholt \& Yule, 2006).

Assessing the risk factors for psychological disorders indicated that there is a significant difference between the genders in this regard, as it was witnessed that women and men are different in coping with challenges arising therein. While male asylum-seekers generally feel depressed because of the separation, physical symptoms are more common in refugee women. In women, these symptoms appear as chest pain, back and heart pain, palpitations, pain throughout the body, weakness, dry mouth, cold eyes and feet, and tremors. In addition, symptoms such as intense crying, emotional 
outbursts, loss of libido, and dread were observed more frequently in refugee women (Renner \& Salem, 2009, p. 99-108).

\section{Provision of health-care services for refugees and asylum-seekers}

Health-care services offered to asylum-seekers and refugees greatly vary from state to state, but it is safe to say that no state in world can claim that has provided adequate health care for its incoming refugees. As such, all immigrants have difficulty accessing basic health care worldwide (Council, 2008, p. 577-656).

Many global institutions and organizations have a responsibility to guarantee that adequate levels of health-care services are provided to asylumseekers and refugees and to protect their health. The most important are local governments, the United Nations, and international and national NGOs that have the opportunity to take genuine steps. The following is list of recommendations for improving health and providing a full range of services (UNHCR, 2007):

- Providing all services in accordance with human rights and human dignity, and preventing discrimination in the provision of services

- Screening for infectious and chronic diseases and offering free treatment after screening

- Providing free immunization procedures (e.g., vaccination) and pregnancy control methods and providing information in this regard

- Performing screening, immunization and control measures in infectious diseases

- Providing mental health services

- Keeping communities under constant medical monitoring and evaluation, recording health indicators, especially events such as birth and death;

- Providing basic needs such as free residence, food, medicine, clean water and ongoing support

- Seeking solutions to facilitate the provision of services to refugees and asylum seekers who do not know the language of that country.

- Ensuring the sustainability of health services provided to refugees and asylum seekers 


\section{Social rights of refugees and asylum seekers in international conventions}

As a reflection of neoliberal policies in the economy, goals such as competition, maximizing profits, and minimizing labor costs have attained paramount importance. Asylum-seekers and refugees often adapt to this trend to make a living in the country to which they resort. The neoliberal economic order is taking advantage of this obligation imposed on refugees, and the sustained migration and the increase in the number of refugees is exacerbating this. This situation, which directly influences working conditions and incomes, makes the protection of social security inefficient and leads to fundamental human rights violations. Nevertheless, refugees are forced to continue working even without having their needs met in the favor of capitalists who seek to further reduce labor costs. By turning inequality into barriers, a vicious cycle is formed, exposing refugees to further exploitation.

Alterations in social status and varying understandings have changed society's view of social rights. Accordingly, the attitude towards the poor hiving social rights has changed a lot in a negative way. Considering the negative attitude towards poor citizens, strong xenophobic reactions to refugees are unavoidable (Turuk Dugan \& Uchpinar, 2011, p. 246). The current situation puts the social rights of people and groups that are relatively weak in society on the agenda, and for this, measures must be devised so that they can live a life worthy of human dignity (Tanur, 1978, p. 100).

The trend created by globalization has largely placed refugees the target of neoliberal economic policies, making them a global issue in terms of human rights protection. However, this has been shown in the form of donations such as contributions through charities, which has impaired the quality of this issue. Social rights and fundamental human rights are vanishing with the realization that government responsibility has weakened and these charities have taken over the responsibilities (Backlaji \& Nurcan, 2009).

Legal instruments on international human rights complement and influence each other. Documents developed on refugees must be assessed in conjunction with a wide range of rights that should not restrict the Convention in regards to the asylum seekers enjoying the social rights they require (Hathaway, 2007).

Social rights are frequently mentioned in the context of human rights instruments such as The International Bill of Human Rights, itself including the Universal Declaration of Human Rights (UDHR), the International Covenant on 
Economic, Social and Cultural Rights known as the United Nations Twin Conventions, and the International Covenant on Civil and Political Rights. By using the terms "all, all people", these conventions were broad enough to cover the rights of all people. The Convention on the Legal Status of Refugees must also be interpreted in the context of its specific objectives and in conjunction with international legal instruments on human rights. Accordingly, refugees can gain access to social rights through paving the way for widespread interpretation (Hathaway, 2007, p. 8). However, as is often criticized, national courts tend to interpret refugees' rights in a limited way, even though these rights require to be interpreted broadly (Coleman, 2003, p. 23).

The treaty that establishes in detail the status of refugees and asylumseekers and the rights they can employ in the international arena is the 1951 Geneva Convention Relating to the Status of Refugees. In addition, a Protocol was signed in 1967 in New York. In addition, the right to asylum is enshrined in the Universal Declaration of Human Rights because of its refugee activities at the United Nations (Alton Ichik \& Yilidirim, 2002, p. 18-19). One of the rather significant UN action on refugees is the establishment of the United Nations High Commissioner for Refugees (UNHCR). The organization was established by the decision of the United Nations General Assembly with the agenda of providing permanent solutions to the issued facing refugees as the main body responsible for refugees.

There is a conceptual difference between the immigrant and the asylum seeker in the implementation of these rights. Refugee status becomes important when attaining a legal status as an asylum seeker. An asylum seeker is a person who has been in a short-term asylum situation and whose legal status is yet to be determined. An asylum seeker may be someone who has applied for asylum but whose application has not yet been finalized. Asylum seekers seek international protection, but this request for protection may not always be granted, implying that not all asylum seekers receive refugee status (Chilkli, 2009, Acer et al., 2010).

The Convention on the Legal Status of Refugees contains 46 articles, Articles 20 and 24 regulate the social conditions of refugees. Article 21 provides the right of refugees to housing, Article 22 focuses on the right to education, Article 23 pertains social benefits and Article 24 deals with the government's non-discrimination in the areas of labor and social security. The Convention has provided an extensive list of social rights such as social security rights, job security, payroll and business appointments. 
The convention requires that, in housing law, the member states must recognize the rights of refugees in terms of access to residence, and in this regard, asylum-seekers must be treated as other foreigners with similar conditions. It is stipulated that in recognition of the right to education, refugees should be given proper education that is not different from that provided to the citizens of that country. In addition, asylum seekers should be treated as other foreigners in matters other than basic education-related rights.

Article 23, which regulates social assistance, has urged party states to provide refugees with services they provide as social assistance to their own citizens. Article 24 contains a very extensive list of rights and also states that there should be no discrimination in the exercise of the listed rights. Accordingly, there should be no discrimination against refugees in areas such as wages, overtime, family allowance, paid leave, internships, vocational training, group visits and hourly wages. If a refugee dies due to an accident at work or an occupational disease, his/her relatives should be entitled to a monetary compensation. moreover, refugees must be able to enjoy the benefits of social security or the new rights that are being considered, provided that the applicable prerequisites exist for the citizens of the country. However, Article 24.4 encourages states to expand and increase the rights of refugees. Considering these articles, it can be seen that the principle that prevails in terms of social rights in the Convention on the Legal Status of Refugees is the prohibition of discrimination (Hathaway, 2007, p. 39-40, Marouf \& Anker, 2009, p. 785). The rights of immigrants should be the same as the people of that country.

Article 8 of the UNHCR also regulates the scope of protection of refugees on the international stage. As previously stated, the fundamental principle in exploiting the basic rights and freedoms by the refugees is non-discrimination. Refugees should be treated like other citizens in most areas of social rights (basic education, social assistance, and social security rights among others) (Loux, 1998, p. 298-299).

The international protection of asylum-seeker should not be limited to the protection of their physical health and safety. Protecting mechanisms and safeguards are also of utmost importance for refugees to enjoy their rights. Refugees should at least be able to enjoy the rights of foreigners in their country of origin. The individual needs of refugees must also be met. In this regard, refugee children should be given basic education, every refugee should be able to receive the health care they need, and every refugee who applies for residence should be able to exercise their right to work and housing. 
Furthermore, immigrants must be able to appreciate the social rights granted thereto in cases such as pregnancy and occupational diseases in the field of social security.

Articles 31 and 32 of the Convention on the Legal Status of Refugees has established the principle of non-return of migrants. Failure to recognize the economic and social rights of asylum seekers and refugees and failure to exercise these rights is deemed a violation of this fundamental principle (Cholewinski, 2004, Gammeltoft-Hansen, 2011).

The European Social Charter is the economic and social rights equivalent of the European Convention on Human Rights. The provisions of this treaty are important in the context of social protection, including the right to health, the right to social security and the right to social and medical assistance (De Shutter, 2010, p. 25). Nevertheless, the above-mentioned convention only applies the citizens of the member states.

However, the Economic and Social Committee, having previously examined these cases in filed lawsuits, has shown that the treaty is a dynamic document based on values such as equality and mutual assistance, themselves relying on the Vienna Convention on the Law of Treaties. According to the committee, the provision of health services is a precondition for the protection of human dignity, because the right to health is related to the right to life and is directly related to human dignity. Furthermore, in the Committee's view, the enactment of laws barring the provision of medical assistance to foreign nationals within the borders of a member state is contrary to the Charter, even if those persons have passed borders illegally.

\section{Support for refugees and asylum-seekers - women, children and the elderly)}

Refugees are often vulnerable to various types of violence because they are deprived of the support of their families and communities, as well as the legal support of the country of which they are citizens to. Widespread reports indicate that refugees and asylum seekers are physically and sexually abused by other refugees, officials, locals and even the security forces of the destination country. In order to avert these aggressions, the conditions that give rise to such tragedies must be corrected, the security forces and the authorities must be properly trained, and such crimes must be legally pursued and punished. Organizing the order of life in the refugee camps, providing lighting, and monitoring the environment can highly contribute to the prevention of 
harassments. In addition, refugee groups can be encouraged to turn to night patrol organizations, especially in cases where security inside the camps is not fully guaranteed.

International documents and articles have recognized that there are groups of refugees who are in a relatively more vulnerable position. Women, children and the elderly are often in a more vulnerable position. Offering protection for refugee women and children against sexual labor, sexual and physical abuse, and violence and discrimination in the distribution of goods and services is of paramount importance. Furthermore, the design of refugee camps often heightens the threat to refugee women. Public living spaces that do not respect privacy, long-distance toilets that are unsafe, and insufficient lighting put women in more challenging situations.

Moreover, children and infants also need special protection due to their helplessness and dependence and being in a stage of nurture and development. Almost half of all refugees worldwide are children. Adolescents go through this period when they complete their psychological development. They are highly prone to violence and abuse in stages of life in which they generally need to acquire skills and form personality in a completely unfamiliar environment. According to the United Nations Convention on the Rights of the Child (UNHCR, 2018) (commonly abbreviated as the CRC or UNCRC), party states must take appropriate measures for children seeking asylum and provide the essential assistance and support to the child. Providing basic health services, nutrition and education is essential for a child's healthy physical nurturing and mental development. In addition, these children should be encouraged to acquire new skills and participate in society. Birth registration in the refugee country is highly critical for the future of asylum-seeking children.

More senior refugees face almost the same problems everywhere; lack of job and education opportunities and lack of knowledge on how to benefit from services are issues that are often neglected or abandoned by family members. The age limits for seeking asylum seeker varies from region to region, as a person is considered old in Africa in his/her 40s, while in Latin America, a person is considered old when he/she reaches the 70 years old mark. Poor health-care services, deprived living conditions and malnutrition expose elderly refugees to illness and significantly reduce their life expectancy. Refugees cannot benefit from medical innovations, and hence they cannot enjoy their full human rights. 


\section{CONCLUSION}

This paper examines the status quo of people who are forcibly placed in refuge and asylum and are forced to leave their permanent country. While refugees today should enjoy full human rights, the government's resort to introverted actions deprives their own citizens of enjoying human rights. since human rights conventions point out the fact that all people should enjoy the full and equal rights, the health rights of refugees should be equal to the rights of the citizens of the countries to which they have sought asylum.

It seems that the UN Refugee Council and the Health Care Organization need to convene on developing a priority global program for addressing the refugee health issue. If the national economies of countries, which are declining during the globalization period, does not recover, new waves of migration from poor to rich countries are expected at the international level, and hence a global migration program must be developed and implemented primarily to improve the conditions of refugees. In order to avoid the vanishing of refugees and prevent them from dying while crossing sea borders, a new international refugee plan must be implemented under the patronage of the United Nations. While global warming is causing drought in many parts of the world, factories in rich countries certainly need to be properly managed.

As the unlimited production of the rich upsets the balance of the world, a new sustainable development plan must be implemented. Talking about the right to health of refugees will only be possible after such measures are taken.

\section{REFERENCES}

Acer, Y., Kaya, I., \& Gumus, M. (2010). Asylum Strategy in a Global and Regional Perspective. Ankara: Osuk Publications.

Alton Ichik, Ch., \& Yilidirim, M. Sh. (2002). Protection of Refugee Rights. Ankara: Ankara Bar Association Publications. pp. 18-19.

Backlaji, o., \& Nurcan, O. (2009). Reconstruction of Refugees in Charities: From the International Social Actor to the Issue of Charity.

Betancourt, T. S., Newnham, E. A., Layne, C. M., Kim, S., Steinberg, A. M., Ellis, H., \& Birman, D. (2012). Trauma history and psychopathology in war-affected refugee children referred for trauma-related mental health services in the United States. Journal of Traumatic Stress, 25(6), 682-690. 
Buze, S. (2002). Problems Faced by Immigrants to Turkey While Waiting to Travel to a Third Country (M.Sc. Thesis, Hacettepe University Institute of Social Sciences, Ankara, Turkey). (p. 7).

Buze, S. (2004). Forced Departure and Forced Admission of Refugees, Association of the Union of Refugees and Asylum-seekers, Ankara.

Buze, S. (2008). Social Profile of Refugees in Turkey. Journal of Police Sciences, 10 (4), 1-14.

Cara, P., \& Kercut, R. (2010). Immigration, Asylum and Refuge in Turkey. Turkish Administrative Journal, 467, 155.

CDC. (Erişim Tarihi: 12.11.2018). Save The Children, Emergency Health and Nutrition Toolkit: From Development to Emergency Preparedness and Response. https://www.ennonline.net/attachments/589/ehn-toolkitflyer.pdf.

Chilkli, B. (2009). Asylum Seekers and Immigrants in International Law. Ankara: Sechkin Publishing House.

Cholewinski, R. (2004, November). Overview of social and economic rights of refugees and asylum seekers in Europe: International obligationsEducation and Employment. In ECRE Conference on Social and Economic Rights of Refugees and Asylum Seekers-Education and Employment, Odessa, Ukraine.

Coleman, N. (2003). Non-refoulement revised renewed review of the status of the principle of non-refoulement as customary international law. European Journal of Migration and Law, 5, 23-68.

Council, R. (2005). A Study of Asylum Seekers with Special Needs London: Refugee Council.

Dahlin, C. (2019). Prevention and response to sexual and gender based violence in refugee settlements in Uganda: a qualitative study concerning the experiences of staff working with sexual and gender based violence in refugee settlements in Uganda.

De Shutter, O. (2010). The Social Conditions of Europe, The New Constitution for Europe. European Assembly, p. 25. 
Ehntholt, K. A., \& Yule, W. (2006). Practitioner Review: Assessment and treatment of refugee children and adolescents who have experienced war-related trauma. Journal of Child Psychology and Psychiatry, 47(12), 1197-1210.

Frantz, E. (2003). Report on the situation of refugees in Turkey: Findings of a five-week exploratory study December 2002-January 2003. Forced Migration and Refugee Studies. American University of Cairo.

Gammeltoft-Hansen, T. (2011). Access to asylum: International refugee law and the globalisation of migration control (Vol. 77). Cambridge University Press.

Ghent, A. (2008). Overcoming migrants' barriers to health. World Health Organization. Bulletin of the World Health Organization, 86(8), 583.

Guken, S. (2011). Effects of Harassment on Women as a Weapon of War. TAF Preventive Medicine Bulletin, 10 (1), 119-126.

Gündüz Yeşil Yurt, Z. (2011). The Health Status of Turkish Immigrants Based in Germany: Suggestions for Moving From 'Immigration Sick' to 'Immigration Health', They Are Our Citizens, The Cultural Opening of Immigration and International Migration Services.

Hathaway, James C. (2007). The Law of Refugee Status, Toronto: Butterworths, 1991. Foster, Michelle, International Reugee Law and Socio-Economic Rights, Cambridge: Cambridge University Press.

Helsinki Citizens' Association. (2007). Uninvited Guests: Immigrants kept in Turkish foreign inns. Refugee Monitoring Report.

Jastram, K., \& Achiron, M. (2001). Refugee protection: a guide to international refugee law. Inter-Parliamentary Union.

Karadag, O., \& Altinbash, K. Hakan. (2010). Refugees and Health. TAF Preventive Medicine Bulletin, 1, 2010.

Kirmayer, L. J., Narasiah, L., Munoz, M., Rashid, M., Ryder, A. G., Guzder, J., \& Pottie, K. (2011). Common mental health problems in immigrants and refugees: general approach in primary care. Cmaj, 183(12), E959-E967. 
Loux, G. (1998). Goodwin-GUI, THE REFUGEE IN INTERNATIONAL LAW Oxford: Clarendon Press, 1996. 2nd edn. xl and 584 pp. ISBN 019826020 $2(\mathrm{pb}) . £ 22.50$.

Marouf, F. E., \& Anker, D. (2009). Socioeconomic Rights and Refugee Status: Deepening the Dialogue Between Human Rights and Refugee Law. The American Journal of International Law, 103(4), 784-796.

Nicholl, C., \& Thompson, A. (2004). The psychological treatment of Post Traumatic Stress Disorder (PTSD) in adult refugees: A review of the current state of psychological therapies. Journal of Mental Health, 13(4), 351-362.

Office of the United Nations High Commissioner for Refugees in Turkey. (accessed:8/14/2018).http://unhcr.org.tr/MEP/index.aspx?pagekey=multec ikimdir.

Özel Turk Tahmazoglu, Sultan. (2012). Health Rights from a Constitutional Perspective. Istanbul: Legal.

Ozturk, O., \& Oglu Sahin, I. (2008). Health and Mental Problems. Ankara: Nobel Book House.

Renner, W., \& Salem, I. (2009). Post-traumatic stress in asylum seekers and refugees from Chechnya, Afghanistan, and West Africa: gender differences in symptomatology and coping. International Journal of Social Psychiatry, 55(2), 99-108.

Sur, H. (2012). Experiences related to migration and its effects with the help of social learning theories. Journal of Social Science (Dumlupinar University), 32,53 .

Tanur, B. (1978). Social Law in Constitutional Law. Istanbul: May Publications.

Teodorescu, D. S., Heir, T., Hauff, E., Wentzel-Larsen, T. O. R. E., \& Lien, L. (2012). Mental health problems and post-migration stress among multi-traumatized refugees attending outpatient clinics upon resettlement to Norway. Scandinavian journal of psychology, 53(4), 316-332.

Turuk Dugan, A., \& Uchpinar, O. (2011). Guidelines for Monitoring the Refugee and Asylum Seekers. Ankara: Turkish Human Rights Endowment Publications. 246. 
UNHCR, Asylum Problem, Global Refugee Status. (1997), Ankara: UNHCR Publications.

UNHCR, Handbook of Criteria and Procedures for Determining Refugee Status. (1998), Ankara: UNHCR Publications.

UNHCR. (2007). Handbook for Emergencies, 3rd Edition, Geneva, Helsinki Citizens' Exit, Expected Guests: "Foreign Guests in Turkey" by Tutulan Mülteciler, Mülteci Gözetim Report.

United Nations High Commissioner for Refugees (UNHCR), OAU (African Union Convention on the Regulation of Specific Aspects of Refugees in Africa). (1998), International Legal Documents on Asylum and Refugee Issues.

United Nations High Commissioner for Refugees (UNHCR). (2007). Handbook for emergencies. United Nations High Commissioner for Refugees.

United Nations High Commissioner for Refugees. (1998), Criteria and Procedures for Determining Refugee Status.

Warfa, N., Curtis, S., Watters, C., Carswell, K., Ingleby, D., \& Bhui, K. (2012). Migration experiences, employment status and psychological distress among Somali immigrants: a mixed-method international study. BMC public health, 12(1), 1-12. 